\title{
Review
}

\section{Sustainable Amelioration of Heavy Metals in Soil Ecosystem: Existing Developments to Emerging Trends}

\author{
Garima Awasthi ${ }^{1}$, Varad Nagar ${ }^{2}$ D, Saglara Mandzhieva ${ }^{3, *}$, Tatiana Minkina ${ }^{3}$, Mahipal Singh Sankhla ${ }^{2} \mathbb{D}$, \\ Pritam P. Pandit ${ }^{2}$, Vinay Aseri ${ }^{2} \mathbb{D}$, Kumud Kant Awasthi ${ }^{1}$, Vishnu D. Rajput ${ }^{3} \mathbb{D}$, Tatiana Bauer $^{3}$ \\ and Sudhakar Srivastava $4, *$ (D)
}

1 Department of Life Sciences, Vivekananda Global University, Jaipur 303012, India; gariimaa21@gmail.com (G.A.); kumud.awasthi@vgu.ac.in (K.K.A.)

2 Department of Forensic Science, Vivekananda Global University, Jaipur 303012, India; varad.leo10@gmail.com (V.N.); mahi4n6@gmail.com (M.S.S.); panditpritam086@gmail.com (P.P.P.); vinayaseri510@outlook.com (V.A.)

3 Academy of Biology and Biotechnology, Southern Federal University, Rostov-on-Don 344090, Russia; tminkina@mail.ru (T.M.); rajput.vishnu@gmail.com (V.D.R.); bauertatyana@mail.ru (T.B.)

4 Plant Stress Biology Laboratory, Institute of Environment \& Sustainable Development, Banaras Hindu University, Varanasi 221005, India

* Correspondence: msaglara@mail.ru (S.M.); sudhakar.iesd@bhu.ac.in (S.S.)

\section{check for}

updates

Citation: Awasthi, G.; Nagar, V.; Mandzhieva, S.; Minkina, T.; Sankhla, M.S.; Pandit, P.P.; Aseri, V.; Awasthi, K.K.; Rajput, V.D.; Bauer, T.; et al. Sustainable Amelioration of Heavy Metals in Soil Ecosystem: Existing Developments to Emerging Trends. Minerals 2022, 12, 85. https:// doi.org/10.3390/min12010085

Academic Editor:

Kyoung-Woong Kim

Received: 15 December 2021

Accepted: 7 January 2022

Published: 12 January 2022

Publisher's Note: MDPI stays neutral with regard to jurisdictional claims in published maps and institutional affiliations.

Copyright: (C) 2022 by the authors. Licensee MDPI, Basel, Switzerland. This article is an open access article distributed under the terms and conditions of the Creative Commons Attribution (CC BY) license (https:// creativecommons.org/licenses/by/ $4.0 /)$.

\begin{abstract}
The consequences of heavy metal contamination are progressively degrading soil quality in this modern period of industry. Due to this reason, improvement of the soil quality is necessary. Remediation is a method of removing pollutants from the root zone of plants in order to minimize stress and increase yield of plants grown in it. The use of plants to remove toxins from the soil, such as heavy metals, trace elements, organic chemicals, and radioactive substances, is referred to as bioremediation. Biochar and fly ash techniques are also studied for effectiveness in improving the quality of contaminated soil. This review compiles amelioration technologies and how they are used in the field. It also explains how nanoparticles are becoming a popular method of desalination, as well as how they can be employed in heavy metal phytoremediation.
\end{abstract}

Keywords: heavy metal; remediation; environmental; phytoremediation; nanotechnology

\section{Introduction}

Today, the world faces many problems, one of which is heavy metal (HM) pollution. During mining from ores, heavy metals are transported and these elements are released into the environment when mined for various purposes. The problem of spills from HM deposits is endangered by the cumulative effects of industrial development and disruption of the regular biogeochemical cycle [1]. Soil is a compound mixture and a non-renewable natural resource, as it can only be restored on a geological timescale. It can be easily defined as the loose inorganic or organic matter of the surface that assists as a natural habitat for terrestrial plants [2]. Heavy metals are very hazardous to the environment and living things. It can be strengthened by the food chain. When the soil is exposed to HM adulteration, landfilling is tough [3]. Potentially toxic elements and metalloids in soil ("heavy metals") have raised serious alarm due to their effects on humans and ecosystems [4-7].

Heavy metals causing soil pollution based on human actions such as mining, steelworks, and electroplating negatively affect human health and ecosystem stabilization [8,9]. From much research in recent years, a large number of studies have described how plants are capable of $\mathrm{HM}$ accumulation/elimination. In this review study, the different techniques used for tackling soil adulteration due to HMs, the HMs have been removed using biochar, fly ash, and bioremediation techniques and recent advances suggested in nanotechnology combined with bioremediation which were found to be more effective and some methods cheaper than other techniques were discussed. 
Bioremediation is a type of ecological remediation that concentrates on minimizing clean-up actions' environmental footprint. In addition to environmental considerations, sustainable repair covers social and economic factors [10]. Three stages have occurred in the clean-up sector [11]. Because of unreasonable regulatory demands and public pressure, remediation professionals were originally expected to "eliminate every last trace of contamination". By the 1990s, however, many countries had learned that the price of a "remove all" plan would much outweigh the ostensible social gains. Significant biogeophysical restrictions make it impossible to restore polluted soils to their original state, according to remediation practitioners. As a result, a compromise option was proposed, with remediation aimed at making property acceptable for specific uses [11]. Remediation of HM-contaminated soil has gained popularity as a cost-effective and ecologically friendly way of remediation. Additionally, previous research has shown that phytoremediation is environmentally adaptable, and that it can be utilized in tailings, agricultural soils, and industrial land. Furthermore, phytoremediation produces no secondary contamination, and HM-mixed biomass can be treated using a variety of methods, such as composting, pyrolysis, phytomining, thermal upgrade, and liquid withdrawal [12].

Heavy metal pollution and salinity have harmed arid and semiarid regions [13]. Bioremediation is a type of "Green and Sustainable Refurbishment" (GSR) since it is concerned with environmental issues. Green remediation is defined as "the process of examining all environmental aspects of remedy implementation and combining options to optimize net benefit to the environment of clean-up actions" by the U.S. Environmental Protection Agency (USEPA) [14]. Therefore, a risk-based remediation was created. This makes it possible to set repair standards for contaminated sites to more realistic and acceptable levels. This depended on the scientific evidence that remediation actions themselves can have adverse effects (e.g., greenhouse gas emissions, air pollution, groundwater infection, and eutrophication), and the fact that stakeholders consider 'sustainability' as a necessity.

We need such sustanaible amelioration methods which minimize modern society's growing impact on environment, society, and economy [15-17]. A variety of approaches can be used to eliminate HM cotamination. Traditional remediation technologies, including consolidation/stabilization based on Portland cement [18], containment [19], soil washing, electrokinetic remediation [20], thermal desorption [21], and chemical oxidation/reduction [22], have proven effective for immobilizing, removing, or transforming HMs (i.e., arsenic (As), chromium $(\mathrm{Cr})$ and mercury $(\mathrm{Hg})$ ), making them almost non-toxic. Attempts have been made to maximize ecological, communal, and economic profits through GSR to ensure the sustainability of the refurbishment process (Table 1). We searched google scholar, PubMed, Microsoft Academic or selecting latest and appropriate research for preparing the current review. The keywords like amelioration of HMs in soil, green remediation, nano bioremediation, biochar mediated amelioration, HM contamination, soil pollutant removal, bioremediation, and phytoremediation were used. A total of 132 papers were used for the present review including the construction of Tables. 
Table 1. Advantages and disadvantages of the heavy metals found in soil.

\begin{tabular}{|c|c|c|c|c|}
\hline Sr. No. & Metals & Advantages & Disadvantages & Reference \\
\hline 1 & $\mathrm{Cr}$ & $\begin{array}{l}\text { With increase in } \mathrm{pH} \text { of soil, } \\
\text { leachability of } \mathrm{Cr}(\mathrm{VI}) \text { increased }\end{array}$ & $\begin{array}{l}\mathrm{Cr} \text { is related with sensitive } \\
\text { dermatitis in human beings. }\end{array}$ & [23] \\
\hline 2 & As & $\begin{array}{l}\text { Arsenite can absorb or co-precipitate } \\
\text { with metal sulphite, showing high } \\
\text { empathy for sulphur compound. }\end{array}$ & $\begin{array}{l}\text { Arsenic damage skin, chances of } \\
\text { cancer increases and troubles the } \\
\text { circulatory system. }\end{array}$ & [23] \\
\hline 3 & $\mathrm{~Pb}$ & $\begin{array}{l}\text { Ionic lead, } \mathrm{Pb}(\mathrm{II}) \text {, lead oxides and } \\
\text { hydroxides are unconfined on the } \\
\text { soil, groundwater and surface water. } \\
\text { Most solid form of in soil matrix in } \\
\text { Lead sulphide which forms under } \\
\text { reducing conditions. }\end{array}$ & $\begin{array}{l}\text { Via inhaling or swallowing, lead } \\
\text { builds up in the body (i.e., the brain), } \\
\text { leading to poisoning or death. } \\
\text { Severe harm to the brain, nervous } \\
\text { system, red blood cells, and kidneys. }\end{array}$ & {$[24,25]$} \\
\hline 4 & $\mathrm{Zn}$ & $\begin{array}{l}\text { Zinc is trace element i.e., essential to } \\
\text { humal health. } \\
\text { Sharp reduction in the mitotic } \\
\text { activity. }\end{array}$ & $\begin{array}{l}\text { Water-soluble zinc found in soil } \\
\text { contaminates groundwater. Plants } \\
\text { often accumulate zinc in the soil and } \\
\text { absorb zinc that the system cannot } \\
\text { process. Zinc deficiency causes birth } \\
\text { defects. }\end{array}$ & {$[26,27]$} \\
\hline 5 & $\mathrm{Cd}$ & $\begin{array}{l}\text { Cadmium is very bio-persistent } \\
\text { used in agricultural crops and } \\
\text { sewage sludge (Cd-rich biosolids) } \\
\text { and use of cadmium enrich } \\
\text { phosphate fertiliser. }\end{array}$ & $\begin{array}{l}\text { Cadmium in the body affects } \\
\text { enzymes. Kidney damage is thought } \\
\text { to cause proteinuria. }\end{array}$ & {$[28,29]$} \\
\hline 6 & $\mathrm{Cu}$ & $\begin{array}{l}\text { Connection between soil and water } \\
\text { metal uptake by plants. }\end{array}$ & $\begin{array}{l}\text { Negative effects of metals on crop } \\
\text { growth and yield. }\end{array}$ & {$[30,31]$} \\
\hline 7 & $\mathrm{Hg}$ & $\begin{array}{l}\text { Important sorption of soil sediments } \\
\text { and hemic material. }\end{array}$ & $\begin{array}{c}\text { Mercury is associated with kidney } \\
\text { damage. }\end{array}$ & [23] \\
\hline
\end{tabular}

\section{Heavy Metals Contamination and Toxicity in Soil Ecosystem}

Heavy metal accumulation in the soil is hazardous to the environment and human health, and well-known harmful contaminants have devastating effects on the biological circulation of terrestrial species with variations in the structural composition of nucleic acids, proteins and osmotic balance [32]. Although several remediation techniques such as hardening/stabilization (S/S), soil leaching, electrokinetic remediation, and chemical oxidation/reduction are used to fix, remove, or detoxify HMs in the soil, these traditional approaches do not result in overall sustainability [33].

Metal toxicity not only affects aquatic organisms, but also harmful to soil flora, plants, animals, and humans as well. Oxidative stress results in damage to cell morphology and inhibits cytoplasmic enzymes [34]. Usually, these metals exist in nature individually or in grouping with other elements, but anthropogenic activity increases their concentrations in the environment [35]. Since HMs are water-soluble, they are mainly soluble in solutions. This makes it difficult to remove by physical and chemical separation processes in the soil [36]. Solubility of HMs is determined by their chemical morphology in the environment. So, for improving the remediation efficiency of microbial fuel cell (MFC), appropriate methods for converting HMs into easy-to-move forms (such as acid-soluble fractions) are needed. Some research has used auxiliary reagents like small-molecule organic acids (citric acid, $\mathrm{CA}$; and acetic acid, $\mathrm{HAc})$, inorganic acids $\left(\mathrm{HCl}, \mathrm{HNO}_{3}\right)$, and synthetic chelating agents (ethylenediaminetetraacetic acid, EDTA) [37,38].

These chemicals help in desorbing and dissolving HMs in the soil, allowing them to move around more freely. Synthetic chelating chemicals pose a risk since polymer chelates migrate slowly in electric fields and secondary ecological settings [39]. This study used two small-molecule organic acids (CA, HAc) that are commonly available, reasonably inexpensive, and ecologically benign, as well as a mineral acid $(\mathrm{HCl})$ [39]. The rate of faster improvement of the industrial sector has raised the HM contamination problem, like a hike 
in manufacturing purposes for other metals. Heavy metals like $\mathrm{Cd}, \mathrm{Pb}, \mathrm{As}, \mathrm{Cr}, \mathrm{Cu}$, and $\mathrm{Zn}$ are mainly used in industry and agriculture. Small amounts of these metals are lethal.

Although these metals are present naturally in the environment, tampering occurs when there are large amounts of these metals on land due to continuous mining as well as smelting $[7,40]$. As industrialization progresses and the natural biogeochemical cycle are disrupted, the issue of HM contamination becomes more and more serious. Heavy metals, unlike biological compounds, seldom biodegrade and hence gather in the environment. Accumulation of HMs takes place in the tissues of an organism (bioaccumulation), and their concentrations increase as they transition from low to high trophic levels (biomagnification). Heavy metals in the soil have toxicological consequences on soil microorganisms, which leads to reduced numbers and activity [1].

\section{Sustainable Remediation Strategies}

A number of remediation strategies have been successfully tested and fruitful results have been obtained (Table 2). The following subsections discuss some of the potential approaches.

Table 2. Remediation period and efficiency of heavy metals in soil.

\begin{tabular}{|c|c|c|c|c|c|c|}
\hline Sr. No & Heavy Metals & $\begin{array}{l}\text { Total Metal } \\
\text { Content }\end{array}$ & Method & $\begin{array}{l}\text { Remediation } \\
\text { Period (Days) }\end{array}$ & $\begin{array}{l}\text { Remediation } \\
\text { Efficiency }\end{array}$ & Ref. \\
\hline 1 & $\mathrm{Cu}$ & $800 \mathrm{mg} \mathrm{kg}^{-1}$ & $\begin{array}{c}\text { Cu spiked as well as } \\
\text { equilibrated with additional } \\
\mathrm{Cu} \text { in a } \mathrm{Cu} \text {-contained sandy } \\
\text { soil and the effect of } \mathrm{CMB} \\
\text { amendment was tested }\end{array}$ & 14 & $\begin{array}{c}\text { Reduced Cu by } \\
73 \%\end{array}$ & [41] \\
\hline 2 & As & $120 \mathrm{mg} \mathrm{kg}^{-1}$ & $\begin{array}{c}\text { Biochar applied to an } \\
\text { As-contained paddy soil } \\
\text { under anaerobic conditions } \\
\text { to see how it affected As } \\
\text { release }\end{array}$ & 30 & $\begin{array}{c}\text { Increased As by } \\
234.5 \%\end{array}$ & [42] \\
\hline 3 & $\mathrm{Cd}$ and $\mathrm{Pb}$ & $\begin{array}{c}5 \mathrm{mg} \mathrm{kg}^{-1} \mathrm{Cd} \\
\text { and } \\
100 \mathrm{mg} \mathrm{kg}^{-1} \mathrm{~Pb}\end{array}$ & $\begin{array}{l}\text { The effect of biochar on } \\
\text { metal immobilisation was } \\
\text { studied }\end{array}$ & 1095 & $\begin{array}{c}\text { Reduced } \mathrm{Cd} \\
\text { and } \mathrm{Pb} \text { by } 59 \%\end{array}$ & [43] \\
\hline 4 & $\mathrm{~Pb}$ & $1945 \mathrm{mg} \mathrm{kg}^{-1}$ & $\begin{array}{l}\text { In a polluted soil modified } \\
\text { with charcoal, Pb was } \\
\text { immobilised whereas As } \\
\text { was mobilised }\end{array}$ & 90 & $\begin{array}{c}\text { Reduced } \mathrm{Pb} \text { by } \\
95 \%\end{array}$ & [44] \\
\hline 5 & $\mathrm{Hg}$ & $1000 \mathrm{mg} \mathrm{kg}^{-1}$ & $\begin{array}{l}\text { The activation of PS through } \\
\text { the nanocomposite material } \\
\text { resulted in degradation of } \\
\text { DTZ. DTZ was practically } \\
\text { completely removed using } \\
\text { nanocomposite material. }\end{array}$ & 10 & $\begin{array}{c}\text { Reduced Hg by } \\
94 \%\end{array}$ & [45] \\
\hline 6 & $\mathrm{Cr}$ & $12,285 \mathrm{mg} \mathrm{kg}^{-1}$ & $\begin{array}{l}\text { To evaluate the immobilising } \\
\text { potential and } \\
\text { bioaccumulation of } \mathrm{Cr} \text {, a pot } \\
\text { experiment was done with } \\
\text { three } \mathrm{BC} \text { application rates }\end{array}$ & 77 & $\begin{array}{l}\text { Reduced Cr } \\
\text { between } \\
28-68 \%\end{array}$ & [46] \\
\hline 7 & $\mathrm{Cu}$ & $100 \mathrm{mg} \mathrm{kg}^{-1}$ & $\begin{array}{l}\text { The effect of biochar from } \\
\text { different sources at two rates } \\
\text { of application on the } \mathrm{Cu} \\
\text { distribution in a } \\
\text { Cu-contained soil in two } \\
\text { years incubation }\end{array}$ & 730 & $\begin{array}{c}\text { Reduced Cu by } \\
28 \%\end{array}$ & [47] \\
\hline
\end{tabular}


Table 2. Cont.

\begin{tabular}{|c|c|c|c|c|c|c|}
\hline Sr. No & Heavy Metals & $\begin{array}{c}\text { Total Metal } \\
\text { Content }\end{array}$ & Method & $\begin{array}{l}\text { Remediation } \\
\text { Period (Days) }\end{array}$ & $\begin{array}{l}\text { Remediation } \\
\text { Efficiency }\end{array}$ & Ref. \\
\hline 8 & As and $\mathrm{Cd}$ & $\begin{array}{l}212 \mathrm{mg} \mathrm{kg}^{-1} \mathrm{As} \\
\text { and } \\
10.8 \mathrm{mg} \mathrm{kg}^{-1} \mathrm{Cd}\end{array}$ & $\begin{array}{l}\text { With varying application } \\
\text { rates, the effects of rice-straw } \\
\text { biochar and } \\
\text { iron-impregnated biochar on } \\
\text { Cd as well as As mobility in } \\
\text { the rice rhizosphere, soil to } \\
\text { rice transfer were examined }\end{array}$ & 96 & $\begin{array}{c}\text { Increased As } \\
\text { concentration, } \\
\text { while decreased } \\
\text { Cd }\end{array}$ & [48] \\
\hline 9 & $\mathrm{Cd}$ and $\mathrm{Cu}$ & $\begin{array}{l}3.8 \mathrm{mg} \mathrm{kg}^{-1} \mathrm{Cd} \\
\text { and } \\
134.6 \mathrm{mg} \mathrm{kg}^{-1} \mathrm{Cu}\end{array}$ & $\begin{array}{l}\text { The efficiency of } \\
\text { Phyllostachys pubescens } \\
\text { biochar for immobilising } \mathrm{Cd} \text {, } \\
\mathrm{Cr}, \mathrm{Cu}, \mathrm{Ni}, \mathrm{Pb} \text {, and } \mathrm{Zn} \text { by } \\
\text { lowering the bioavailable } \\
\text { percentage was examined }\end{array}$ & 20 & $\begin{array}{l}\text { Reduced Cd by } \\
31.2 \% \text { and } \mathrm{Cu} \\
\text { by } 79.7 \%\end{array}$ & [49] \\
\hline 10 & $\mathrm{~Pb}$ & $1445 \mathrm{mg} \mathrm{kg}^{-1}$ & $\begin{array}{c}\text { Pb immobilisation in } \\
\text { biochar-treated soils } \\
\text { gathered near an old mine } \\
\text { was tested }\end{array}$ & 45 & $\begin{array}{c}\text { Reduced Pb by } \\
87 \%\end{array}$ & [50] \\
\hline 11 & $\mathrm{Hg}$ & $129 \mathrm{mg} \mathrm{kg}^{-1}$ & $\begin{array}{l}\text { The effects of adding two } \\
\text { biochars (RSB and WSB) to } \\
\text { soil at different doses on Hg } \\
\text { mobility in the pore water of } \\
\text { a contaminated paddy soil } \\
\text { were investigated }\end{array}$ & 118 & $\begin{array}{c}\text { Reduced Hg by } \\
44 \%\end{array}$ & [51] \\
\hline 12 & $\mathrm{Cr}$ & $50 \mathrm{mg} \mathrm{kg}^{-1}$ & $\begin{array}{l}\text { Metals such as Cd and Cr } \\
\text { were artificially added to } \\
\text { air-dried soil and the effect } \\
\text { of biochar-amendment was } \\
\text { evaluated }\end{array}$ & 120 & $\begin{array}{c}\text { Reduced Cr by } \\
48.1 \%\end{array}$ & [52] \\
\hline 13 & $\mathrm{Cu}$ & $1805 \mathrm{mg} \mathrm{kg}^{-1}$ & $\begin{array}{l}\text { Using a naturally contained } \\
\text { shooting range as well as } \\
\text { spiked soils, the } \\
\text { immobilisation and } \\
\text { phytoavailability of } \mathrm{Cd}, \mathrm{Cu} \text {, } \\
\text { and Pb were investigated } \\
\text { with biochar made from } \\
\text { chicken dung and green } \\
\text { garbage were used }\end{array}$ & 14 & $\begin{array}{c}\text { Reduced Cu } \\
79 \%\end{array}$ & [53] \\
\hline 14 & As & $1945 \mathrm{mg} \mathrm{kg}^{-1}$ & $\begin{array}{l}\text { The effects of ten different } \\
\text { biochars on rice growing in } \\
\text { polluted soil were studied. }\end{array}$ & 90 & $\begin{array}{l}\text { Increased As } \\
\text { concentration }\end{array}$ & [44] \\
\hline 15 & $\mathrm{Cd}$ & $1.36 \mathrm{mg} \mathrm{kg}^{-1}$ & $\begin{array}{l}\text { To immobilise } \mathrm{Pb} \text { in polluted } \\
\text { sediment, biochar-supported } \\
\text { nano-chlorapatite } \\
\text { (BC-nClAP) was produced } \\
\text { and tested }\end{array}$ & 6 & $\begin{array}{l}\text { Reduced Cd by } \\
\quad 65.7 \%\end{array}$ & [54] \\
\hline 16 & $\mathrm{~Pb}$ & $589.7 \mathrm{mg} \mathrm{kg}^{-1}$ & $\begin{array}{l}\text { At varying application rates } \\
\text { of polluted paddy soil, } \\
\text { looked into the impact of } \\
\text { biochar alteration in } \\
\text { lowering soil } \mathrm{CO}_{2}, \mathrm{CH}_{4} \text {, and } \\
\mathrm{N}_{2} \mathrm{O} \text { releases and lowering } \\
\text { Cr uptake by rice grains. }\end{array}$ & 30 & $\begin{array}{l}\text { Whole } \\
\text { Reduction }\end{array}$ & [55] \\
\hline
\end{tabular}


Table 2. Cont.

\begin{tabular}{|c|c|c|c|c|c|c|}
\hline Sr. No & Heavy Metals & $\begin{array}{c}\text { Total Metal } \\
\text { Content }\end{array}$ & Method & $\begin{array}{l}\text { Remediation } \\
\text { Period (Days) }\end{array}$ & $\begin{array}{l}\text { Remediation } \\
\text { Efficiency }\end{array}$ & Ref. \\
\hline 17 & $\mathrm{Cr}$ & $432.8 \mathrm{mg} \mathrm{kg}^{-1}$ & $\begin{array}{c}\text { The effect of rice straw } \\
\text { biochar on leaching of DOC } \\
\text { and phosphate across a } \\
\text { variety of biomass feedstock } \\
\text { was tested }\end{array}$ & 122 & $\begin{array}{c}\text { Reduced Cr by } \\
22.3 \%\end{array}$ & [56] \\
\hline 18 & $\mathrm{Cu}$ & $100 \mathrm{mg} \mathrm{kg}^{-1}$ & $\begin{array}{c}\text { Biochars tested for their long } \\
\text { lasting effect on lowering the } \\
\text { bioavailability of } \mathrm{Cd} \text { in } \\
\text { paddy soils. }\end{array}$ & 180 & $\begin{array}{c}\text { Reduced Cu by } \\
41 \%\end{array}$ & [57] \\
\hline 19 & As & $92.3 \mathrm{mg} \mathrm{kg}^{-1}$ & $\begin{array}{c}\text { To stabilise } \\
\text { methylmercury }(\mathrm{MeHg}) \text { in } \\
\text { soil and also limit } \mathrm{MeHg} \\
\text { accumulation in rice grains, } \\
\text { SSB applied to } 2 \\
\mathrm{Hg} \text {-contained soils }\end{array}$ & 35 & $\begin{array}{l}\text { Increased As } \\
\text { concentration }\end{array}$ & [58] \\
\hline 20 & $\mathrm{Cd}$ & $2.04 \mathrm{mg} \mathrm{kg}^{-1}$ & $\begin{array}{l}\text { The immobilisation of } \mathrm{Cr}(\mathrm{VI}) \\
\text { in soil was investigated } \\
\text { using a biochar CMC } \\
\text { stabilised nanoscale iron } \\
\text { sulphide (FeS) composite }\end{array}$ & 180 & $\begin{array}{c}\text { Reduced Cd by } \\
50.4 \%\end{array}$ & [59] \\
\hline 21 & $\mathrm{Hg}$ & $2.1 \mathrm{mg} \mathrm{kg}^{-1}$ & $\begin{array}{l}\text { For understanding the } \\
\text { impact of feedstock, } \\
\text { pyrolysis temperatures, as } \\
\text { well as production } \\
\text { circumstances on } \mathrm{Pb} \\
\text { immobilisation capabilities } \\
\text { of variety of biochars was } \\
\text { tested }\end{array}$ & 119 & $\begin{array}{l}\text { Increased } \mathrm{Hg} \\
\text { by } 67 \%\end{array}$ & [60] \\
\hline 22 & $\mathrm{Cr}$ & $308 \mathrm{mg} \mathrm{kg}^{-1}$ & $\begin{array}{l}\text { The immobilisation of } \mathrm{Cr}(\mathrm{VI}) \\
\text { in soil was investigated by a } \\
\text { biochar-supported CMC } \\
\text { stabilised nanoscale iron } \\
\text { sulphide (FeS) composite. }\end{array}$ & 180 & $\begin{array}{c}\text { Reduced Cr } \\
\text { between } \\
47.1 \%-65.5 \%\end{array}$ & [61] \\
\hline 23 & As & $0.3 \mathrm{mg} \mathrm{kg}^{-1}$ & $\begin{array}{c}\text { In the presence of biochar, } \\
\text { anaerobic microcosms was } \\
\text { created with As-contained } \\
\text { paddy soil for studying As } \\
\text { changes }\end{array}$ & 20 & $\begin{array}{l}\text { Increased As } \\
\text { concentration }\end{array}$ & [62] \\
\hline 24 & $\mathrm{Cu}$ & $338 \mathrm{mg} \mathrm{kg}^{-1}$ & $\begin{array}{l}\text { Cu-contaminated soil was } \\
\text { incubated with CMB or } \\
\text { OHB. Over the course of one } \\
\text { season, the metallophyte } \\
\text { Oenothera picensis was } \\
\text { cultivated (six months). } \\
\text { Using the same soils, same } \\
\text { procedure was performed } \\
\text { for three more seasons }\end{array}$ & 730 & $\begin{array}{c}68 \% \\
\text { (exchangeable } \\
\text { fraction) }\end{array}$ & [63] \\
\hline 25 & $\mathrm{Cr}(\mathrm{VI})$ & $100 \mathrm{mg} \mathrm{kg}^{-1}$ & $\begin{array}{l}\text { For extracting } \mathrm{Cr}(\mathrm{VI}) \text { from } \\
\text { groundwater and soils, } \\
\text { Platanus acerifolia leaves were } \\
\text { used in an unique reactor } \\
\text { that combined adsorption } \\
\text { with a microbial fuel cell }\end{array}$ & 14 & $\begin{array}{c}\text { Reduced } \mathrm{Cr}(\mathrm{VI}) \\
\text { by } 40 \%\end{array}$ & [64] \\
\hline
\end{tabular}


Table 2. Cont.

\begin{tabular}{|c|c|c|c|c|c|c|}
\hline Sr. No & Heavy Metals & $\begin{array}{c}\text { Total Metal } \\
\text { Content }\end{array}$ & Method & $\begin{array}{l}\text { Remediation } \\
\text { Period (Days) }\end{array}$ & $\begin{array}{c}\text { Remediation } \\
\text { Efficiency }\end{array}$ & Ref. \\
\hline 26 & $\mathrm{~Pb}$ and $\mathrm{Zn}$ & $\begin{array}{l}291.1 \mathrm{mg} \mathrm{kg}^{-1} \\
\mathrm{~Pb} \text { and } \\
814.2 \mathrm{mg} \mathrm{kg}^{-1} \mathrm{Zn}\end{array}$ & $\begin{array}{c}\text { SMFCs with various } \\
\text { amounts of wheat straw } \\
\text { were tested and compared in } \\
\text { a variety of setups }\end{array}$ & 100 & $\begin{array}{l}\text { Reduced } \mathrm{Pb} \text { by } \\
37.2 \% \text { and } \mathrm{Zn} \\
\text { by } 15.1 \%\end{array}$ & [65] \\
\hline 27 & $\mathrm{Cr}(\mathrm{VI})$ & $100 \mathrm{mg} \mathrm{kg}^{-1}$ & $\begin{array}{l}\text { Applying microbial fuel cell } \\
\text { technology in fed-batch } \\
\text { mode, } \mathrm{Cr}(\mathrm{VI}) \text {-contained } \\
\text { wastewater treatment was } \\
\text { examined }\end{array}$ & $150 \mathrm{~h}$ & $\begin{array}{l}\text { Whole } \\
\text { reduction }\end{array}$ & [66] \\
\hline
\end{tabular}

Abbreviations used in the table: biochar (BC), chicken manure-derived biochar (CMB), rice shell biochar (RSB), wheat straw biochar (WSB), dissolved organic carbon (DOC), oat hull biochar (OHB), solid-phase microbial fuel cells (SMFC), diltiazem (DTC), and carboxymethyl cellulose (CMC).

\subsection{Nano-Bio Remediation of Heavy Metals: Application and Implications}

In the modern era, the usage of nanoparticles (NPs) in industry, medicine, agriculture and cosmetics has increased significantly [67-80]. Materials with at least one dimension smaller than $100 \mathrm{~nm}$ are commonly referred to as NP. NPs with various particle sizes, shapes, as well as functions are produced as per requirement [81]. Compared to conventional materials, NPs possess a lot of advantages, including increased surface activity, extra reactive sites on the surface, increased catalytic efficiency, and special optical as well as magnetic properties [82-84]. The environmental impact of NPs is discussed in previous research: Hao et al. showed that even at $10 \mathrm{mg} \mathrm{L}^{-1}$, rice contained endophytic fungi sensitive to carbon-based NPs [85]. It is reported that exposure to Ag NPs at a dose of $50 \mathrm{mg} \mathrm{kg}^{-1}$ adversely affects the biomass and quality of peanuts [86]. In addition, low dosages ( 5 and $50 \mathrm{mg} \mathrm{kg}^{-1}$ ) of $\mathrm{NiO}$ had no effect on the survival, reproduction as well as rate of growth of adult earthworms, whereas high dosages ( 200 and $500 \mathrm{mg} / \mathrm{kg}$ ) expressly affects physiological and biochemical effects and turned out to be the endpoint [80]. As many field studies (pilot and life-size) and laboratory studies show, the use of nanotechnology for water remediation, used for drinking purification and pollution control, is very favorable.

There are many reviews of applications based on nanotechnology. However, in order to further elucidate its significance as well as guide development, it is necessary to directly compare existing therapeutic methods with new approaches using nanotechnology. In this review, the effectiveness of nanotechnology and old technologies for water purification as well as environmental improvement to provide industries, researchers, and policy makers with insight into the status of water purification methods, are compared. Contaminants were classified into a wide range of classes and the most gainful methods were compared in each class described in the literature. A case study is also presented that directly compared conventional techniques to nanotechnology-based techniques for similar contaminants. Nanotechnology-based methods are generally considered costly, but many of these offer inexpensive and more operative options to traditional technologies. Additionally, nanobased technologies can be critical to complying with progressively stringent water quality standards, especially to remove new and low-concentration pollutants [87].

All latest techniques as well as industries in pharmaceutical departments are interfaced by nanotechnology [88,89], textile industry [90], electrical industry [91,92], mechanical technology, and environment-related industries. Nanotechnology is considered as the synthesis and processing of nanoscale materials [93]. Their small size is the only cause that increases the cost of these materials [94]. Due to their small size, the surface area to volume ratio is significantly improved and the bandgap is clean and wide. As a result, their optical, physical, and electrical properties differ significantly from large volumes of material. Nanomaterials can be metal, semiconductors, or organic [95]. The generation of artificial NPs is attracting attention as an effective recovery method. In addition to other environmental uses, NPs can be inserted underground in the form of sediment to 
offer conditions for chemical recovery of pollutant columns and for use as adsorbents and catalysts in wastewater treatment processes. Its efficiency is based on its chemical composition, well-defined shape and high specific surface area. Today, many NP products are formulated to effectively remove contaminants. However, there is rising concern about the probable impacts in the secondary life cycle linked with production $[96,97]$.

Biosynthetic NPs help green remediation in a variety of methods. Iron-based NPs should be used directly as a fixative. For example, nano zero ferrous iron (nZVI) by waste tea can be used to reduce $\mathrm{Cr}(\mathrm{VI})$ in soil. Iron oxide NPs made from leaf extract can steady $\mathrm{Cd}$ and As in soil by coprecipitation [98,99]. For additional data on the use of nZVI NPs as well as iron oxide, refer to the reader [100]. Green NPs indirectly aid in soil regeneration. Ag NPs mediated by plant extracts can promote plant growth by increasing soil $\mathrm{pH}$ value, nutrient bioavailability and water retention capacity $[65,68,101]$. Naturally benign nanosized mineral built soil conditioners can be organized with feldspar and lime consuming a mild hydrothermal method [102]. Their use in NPs synthesis is attracting more and more attention. Summarizing the current report on the synthesis of NPs for environmental restoration with the help of plant extracts (bud system). NP recovery in vivo is attained through the occurrence of biomolecules contained in plant extracts.

The precise mechanism of this procedure is not yet fully understood, but amino acids, citric acid, phenol, sugar, membrane protein, tartaric acid, as well as functional groups (alcohols, aldehydes, amines, and ketones of carboxylic acids) also reduce and block reducing agents [67,103-105].

\subsection{Biochar Based Sustainable Amelioration of Soil}

In recent times, biochar has gained increasing courtesy as an environmentally friendly tactic, especially as a weather protection strategy [106] (Figure 1). Biochar is considered as a carbon-rich, fine-grained, porous material formed by the thermal decay of biomass at relatively low temperatures under oxygen-restricted conditions $(<700 \mathrm{C})[76,79,107]$. It is also considered as a predominantly stable and stubborn organic carbon (C) compound formed when biomass (raw material) has a temperature typically between $300{ }^{\circ} \mathrm{C}$ and $100{ }^{\circ} \mathrm{C}$ at low oxygen levels.

Biochar is rich in carbon, porous, and has a large exact surface area, and this exact structure has been shown to be capable of enhancing soil moisture and nutrient retention [108]. Biochars range from crop residues (corn stalks, rice straw, rice husks, rapeseed stalks, etc.), grass, wood, sewage sludge, anaerobic digests, and animal excrement (poultry litter, pig manure, etc.). It can be produced by heat treatment of biological waste, and chicken manure) [109-111]. Biochar interacts with HMs in many ways. Complex formation of the outer sphere, complex of the inner sphere, electrostatic interactions, surficial precipitation, and exchange of ion are potential mechanisms of metal fixation [20,112]. A new trend has appeared in biochar pyrolysis as well as post-pyrolysis transformation plans to increase the metal binding capacity of biochar adsorbents (Table 1) [113]. 

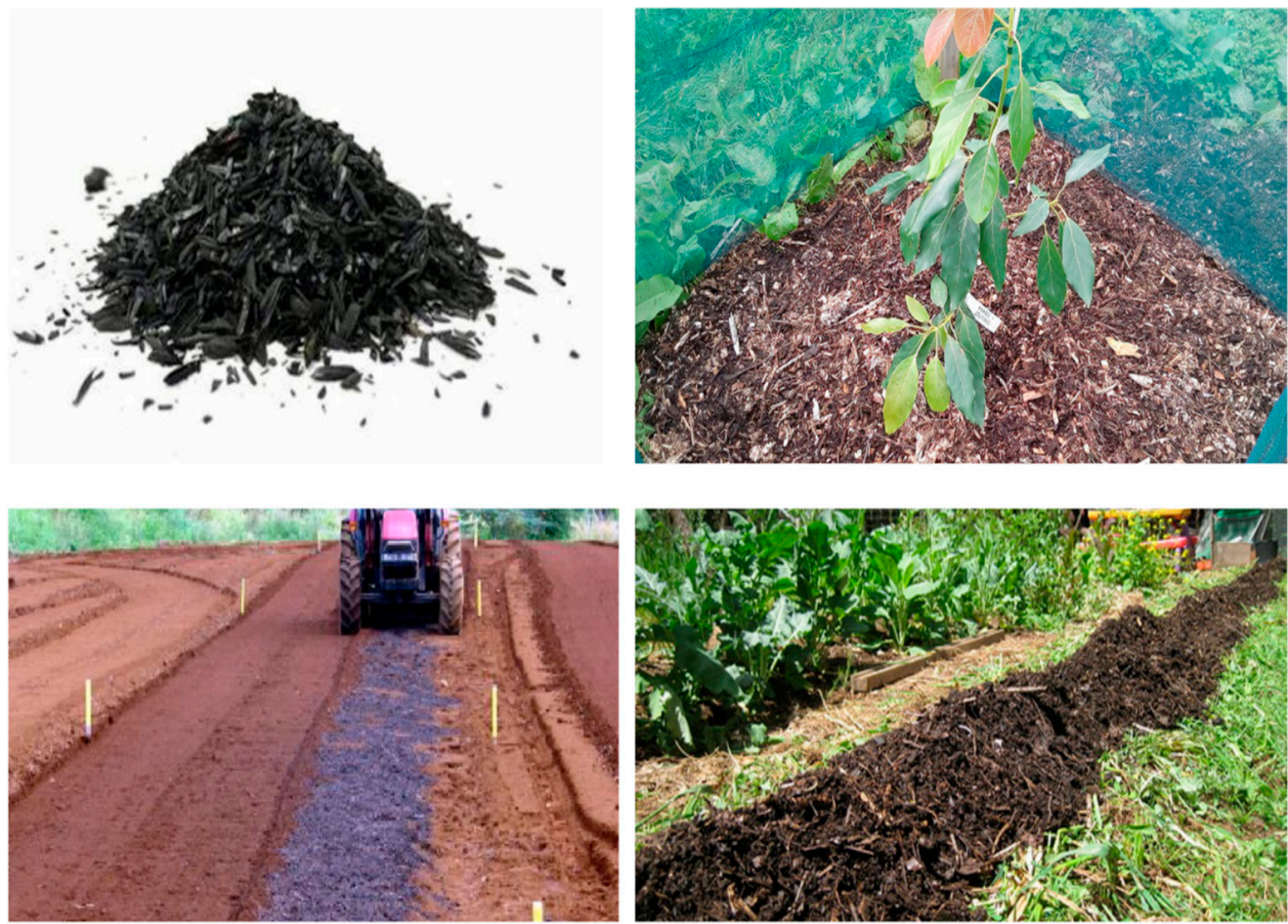

Figure 1. Modified figure of Biochar based sustainable Amelioration of soil figure is adapted from [114-116] with due copyright permission under CC license.

\subsection{Fly Ash- Industrial-Based Materials for Sustainable Remediation}

Since they are mass-produced every year, industrial by-products are attracting attention. Reuse as a soil conditioner is a viable method to the sustainable use of these minimum value by-products. Fly ash from coal combustion is a distinctive byproduct of the coal industry. About 780 million tons are made yearly. The chemical composition of fly ash differs due to its dissimilar source and composition of burned coal, but all types include significant amounts of $\mathrm{SiO}_{2}, \mathrm{Al}_{2} \mathrm{O}_{3}, \mathrm{Fe}_{2} \mathrm{O}_{3}$, and $\mathrm{CaO}[73,116,117]$. It has a similar mechanism of metal immobilization by oxides (i.e., lime and precipitation, surface complexion). The Bayer process in the alumina industry gives red mud as a by-product [118].

However, industrial waste can contain large amounts of poisonous metals as well as organic pollutants. When applied to the soil, these pollutants are out and can move over the long term, posing a danger to the environment [119]. Agriculture, livestock as well as food industries in particular are the major producers of organic waste. Sludge from the sugar industry alone accounts for 30 million tons worldwide [120]. In India alone, the paper industry, which uses large amounts of water and plant cellulose materials, produces 3.033 tons of bio-waste by-products annually from paper mills [121]. In fact, Asian countries have deprived reprocessing systems and faced more ecological problems. Industrial waste is composed of various harmful substances, especially HMs as well as other organic pollutants that affect the quality of the soil. Currently, more than $40 \%$ of bio-waste is landfilled, producing both carbon dioxide and methane [122]. Unlimited greenhouse gas creation from bio-waste landfills that endanger the environment and environmental issues require scientific intervention. As shown, the origin as well as industrial biowaste production can be manageable in a variety of ways, ultimately leading to agriculture. The wastes which are polluted dispose in open places that risk to the environment. Generally, pollutants can be separated into two subgroups: (i) organic and (ii) inorganic [66,123,124]. Currently, contaminated bio-waste is disposed of in vacancies, which are a major cause of environmental pollution, especially water and soil pollution. Therefore, restoration techniques are needed to manage some bio-waste [125] (Figure 2). 

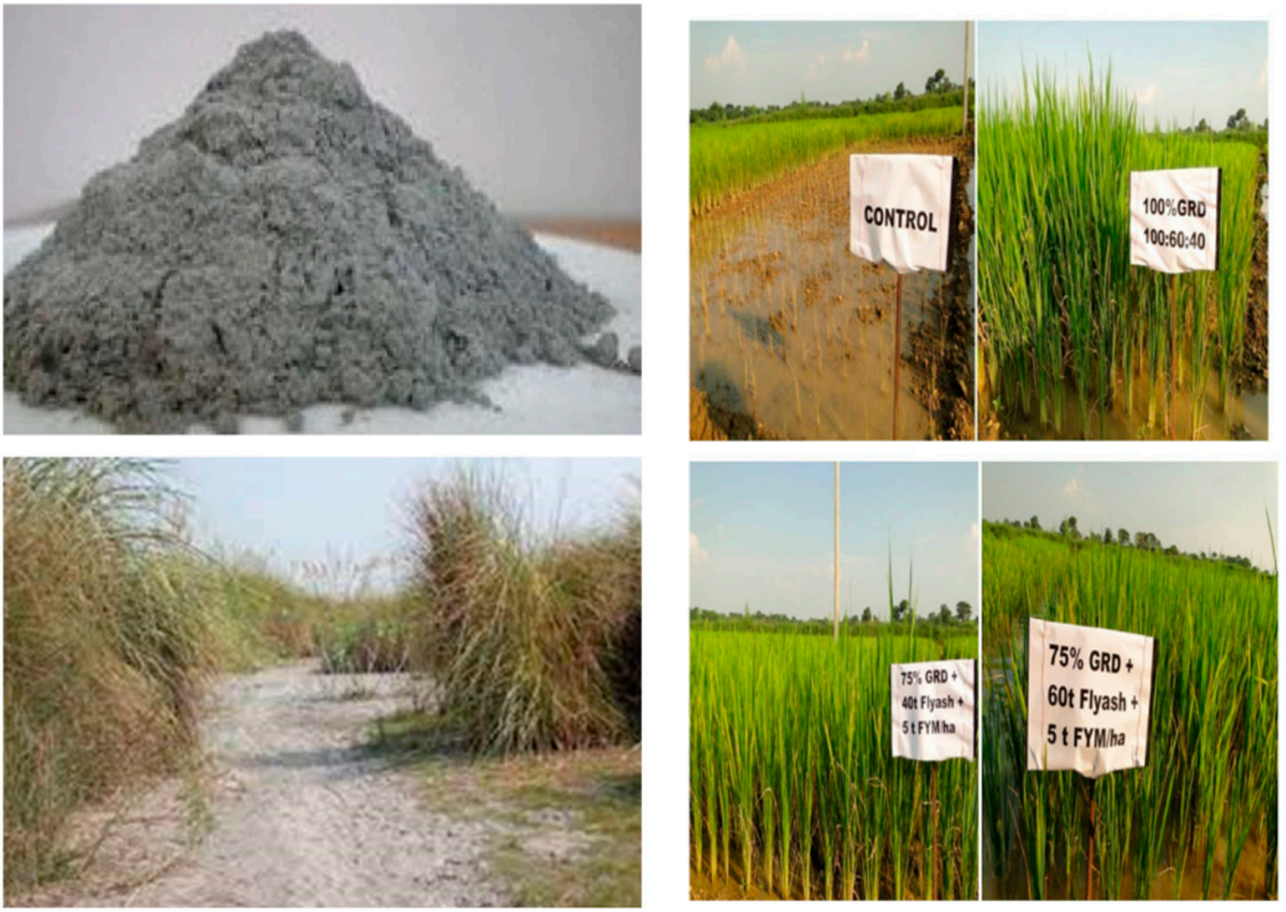

Figure 2. Modified figure of fly ash Industrial-Based Materials for sustainable remediation adapted from $[126,127]$ with due copyright permission under CC license.

\subsection{Employing Bioremediation for Remediation of Contaminated Soil}

Biotechnology which utilizes plants' potential to improve the health of the environment is called phytoremediation. Applied research shows that plants have the capability to eliminate and degrade a range of HM toxicants. Due to being cost effective, simple, sustainable, and being compatible with the environment it is considered as more aesthetic than traditional technologies. Remediation of large amounts of toxic groundwater and treatment of large volumes of diluted wastewater can be implemented in situ. Plants respond differently to metal adulteration in soil and should be divided into different groups depending on their response to metal adulteration in the rooting medium. Plants should be divided as accumulators, indicators, or excluders, dependent on the uptake and movement of metal into the ground by the plant [20]. The phytoremediation technique is simple, inexpensive, sustainable, companionable, environment friendly as well as one of the key contents of green technology.

Plants have the natural capability to break down the HMs through a variety of procedures such as bioaccumulation, translocation, and storage/decomposition of pollutants. Phytoremediation is 10 times more inexpensive than traditional technical approaches because it is field-based, photovoltaic, and can function with minimal post-installation maintenance $[75,77,128]$. Plants have been reported to be highly resistant to HM pollution without causing serious harm; these properties of plants suggest that they could be used to detoxify pollutants through novel approaches to agriculture and genetic engineering. Some of the plants have the natural capability to break down many awkward xenobiotic substances and are therefore considered "green livers" that serve as an essential source of absorption of environmentally harmful chemicals. Nature gives plants the excellent ability to defuse these poisonous elements in the growing matrix, whether in soil or water (Figure 3) [129]. 


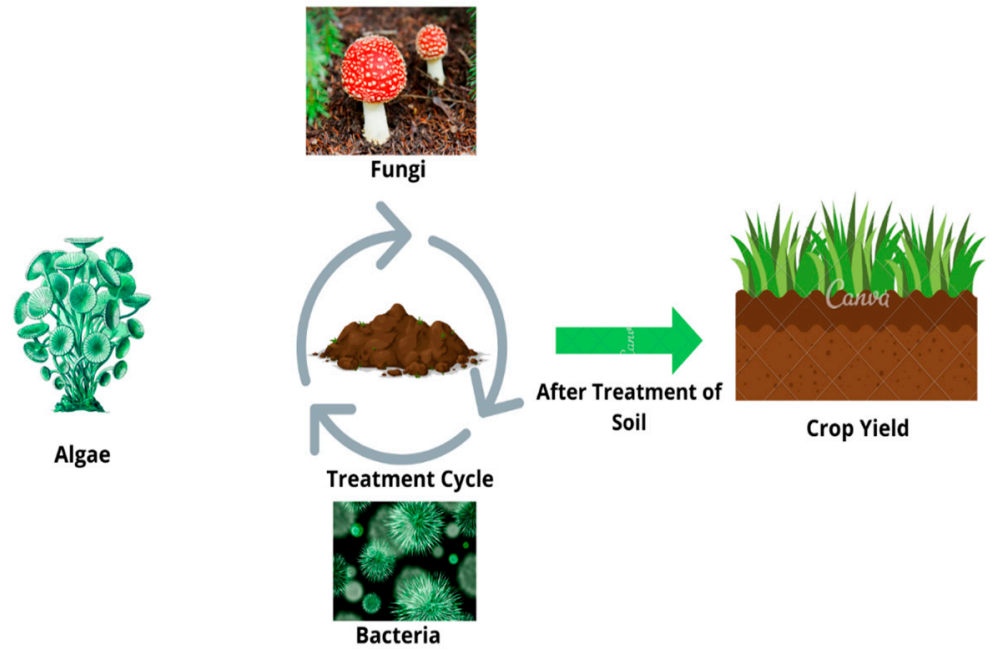

Figure 3. Bioremediation process showing the role of algae, fungi, and bacteria for the enhancement of soil health.

\section{Emerging Trends Challenges and Limitations of Remediation}

Bioremediation is a relatively low-cost solar power field approach. It also produces no secondary waste and is generally accepted by the general public [130]. However, ecofriendly repairs can take longer to set up and fully function than engineering repairs [131]. Another concern is the potential for toxic plants to enter the food market as contaminated wood tissue from the animal food and fuel markets. The depth of pollution is another matter. Reaching contaminants often requires the correct root depth. If root depth is limited, planting in boreholes or pumping contaminated water to shallower depths may be a good alternative. Pollutant heterogeneity is another problem that arises from the spatial and temporal variation of pollutants. In many cases, this requires accurate repair management that combines different methods [131-133].

Green recovery approaches, such as the use of green resources, renewable resource approaches, nature-based resolutions and energy efficiency policies, have received considerable attention. To rehabilitate soils polluted by HMs. However, there are some challenges in this area that can affect overall sustainability: first, post-harvest metal-rich plant tissue can be a source of contamination for plant restoration methods if not disposed of properly. Plant stabilization is only effective inside the biosphere, which cannot clean up the soil deeply. In addition, phytochemical reactions of $\mathrm{Hg}$ lead to air pollution, and the volatile $\mathrm{Hg}$ (mainly elemental mercury) in the atmosphere can arrive to the ecosystem by dry as well as wet deposits. Second, bioremediation materials, like biochar manufactured from contaminated biomass (e.g., plants were used in phytoextraction) and materials derived from industrial wastes containing metals, which can lead to metal dissolution and mobilization. Although many studies have shown that green restoration materials are effective in immobilizing soil metals, their long-lasting stability has not been totally examined. Numerous natural forces such as freezing, erosion, dry-wet cycles, UV radiation, plant growth, and groundwater flows can displace stable metals, posing serious risks in the long term [33].

\section{Conclusions}

Due to the potentially hazardous impacts on humans and soil environments, heavy metal poisoning in soil has sparked a lot of concern. Plants as well as microorganisms plays a vital part in these technologies, the use of green additives like biological and industrial wastes, natural minerals, oxides, and green synthetic nanomaterials that enhance environmental, social, and economic benefits. While some biological remediation strategies, such as plant remediation and soil remediation, are already widely used commercially, other laboratory-proven techniques include biocarbon-based stabilization, low-temperature thermal desorption with citrate, and bio-electrodynamic recovery. In both cases, however, 
practical application-based testing of these green remediation solutions should be done in the future. Due to new methodologies in engineering-based remediation, the use of green remediation to decrease soil salinity is a very promising strategy. The removal of cadmium, chromium, and copper using biochar and fly ash has been found to be an effective technique. On the other hand, HMs like mercury and arsenic were found to be removed with higher efficiency by nano-bioremediation based technologies than by plant or microorganism-based methods. The removal of zinc and lead has been mainly done by using fly ash-based techniques. To bring flexibility in the removal of HMs from soil, traditional techniques combined with nanotechnology can be researched in the future. Bioremediation's biological, physical, and chemical mechanisms, as well as their effects on contaminated soils and streams, will require further research in the future.

Author Contributions: Conceptualization, G.A.; S.S., K.K.A. and V.D.R.; methodology, V.N.; software, V.A. and P.P.P.; validation, M.S.S. and G.A.; formal analysis, G.A. and S.S.; investigation, V.N.; resources, V.N.; data curation, G.A., and V.N.; writing-original draft preparation, G.A. and T.B.; writing-review and editing, S.S.; S.M., T.M., V.D.R. and K.K.A.; visualization, G.A.; supervision, S.S.; project administration, S.M.; T.M. and S.S. All authors have read and agreed to the published version of the manuscript.

Funding: This research received no external funding.

Acknowledgments: The research was financially supported by the Ministry of Science and Higher Education of the Russian Federation project on the development of the Young Scientist Laboratory (no. LabNOTs-21-01AB) and the “Priority 2030" program (no. SP02/S4_0708 Priority_01/SP02/S4_0706 Priority_01).

Conflicts of Interest: The authors declare no conflict of interest.

\section{References}

1. Khan, S.; Hesham, A.E.L.; Qiao, M.; Rehman, S.; He, J.Z. Effects of Cd and Pb on soil microbial community structure and activities. Environ. Sci. Pollut. Res. 2010, 17, 288-296. [CrossRef]

2. Alloway, B.J. Sources of heavy metals and metalloids in soils. In Heavy Metals in Soils; Springer: Berlin/Heidelberg, Germany, 2013; pp. 11-50. [CrossRef]

3. Su, C. A review on heavy metal contamination in the soil worldwide: Situation, impact and remediation techniques. Environ. Skept. Crit. 2014, 3, 24.

4. O'Connor, D.; Hou, D.; Ok, Y.S.; Lanphear, B.P. The effects of iniquitous lead exposure on health. Nat. Sustain. 2020, 3, 77-79. [CrossRef]

5. Wang, L.; Jin, Y.; Weiss, D.J.; Schleicher, N.J.; Wilcke, W.; Wu, L.; Guo, Q.; Chen, J.; O'Connor, D.; Hou, D. Possible application of stable isotope compositions for the identification of metal sources in soil. J. Hazard. Mater. 2021, 407, 124812. [CrossRef]

6. Sankhla, M.S.; Kumari, M.; Nandan, M.; Kumar, R.; Agrawal, P. Heavy metal contamination in soil and their toxic effect on human health: A review study. Int. J. All Res. Educ. Sci. Methods 2016, 4, 13-19.

7. Verma, R.K.; Sankhla, M.S.; Jadhav, E.B.; Parihar, K.; Awasthi, K.K. Phytoremediation of heavy metals extracted soil and aquatic environments: Current advances as well as emerging trends. Biointerface Res. Appl. Chem. 2021, 12, 5486-5509. [CrossRef]

8. Lin, H.; Liu, C.; Li, B.; Dong, Y. Trifolium repens L. regulated phytoremediation of heavy metal contaminated soil by promoting soil enzyme activities and beneficial rhizosphere associated microorganisms. J. Hazard. Mater. 2021, 402, 123829. [CrossRef] [PubMed]

9. Zhao, X.; Joo, J.C.; Kim, J.Y.J.C. Evaluation of heavy metal phytotoxicity to Helianthus annuus L. using seedling vigor index-soil model. Chemosphere 2021, 275, 130026. [CrossRef] [PubMed]

10. Simpkin, T.J.; Favara, P. Overview of Green and Sustainable Remediation for Soil and Groundwater Remediation. In Proceedings of the Waste Management 2012 Conference on Improving the Future in Waste Management, Phoenix, AZ, USA, 26 February-1 March 2012.

11. Dubey, K.K. Food industry waste biorefineries: Future energy, valuable recovery, and waste treatment. In Refining Biomass Residues for Sustainable Energy and Bioproducts; Elsevier: Amsterdam, The Netherlands, 2020; pp. 391-406. [CrossRef]

12. Cui, X.; Shen, Y.; Yang, Q.; Kawi, S.; He, Z.; Yang, X.; Wang, C.H. Simultaneous syngas and biochar production during heavy metal separation from Cd/Zn hyperaccumulator (Sedum alfredii) by gasification. Chem. Eng. J. 2018, 347, 543-551. [CrossRef]

13. Liang, L.; Liu, W.; Sun, Y.; Huo, X.; Li, S.; Zhou, Q. Phytoremediation of heavy metal contaminated saline soils using halophytes: Current progress and future perspectives. Environ. Rev. 2017, 25, 269-281. [CrossRef]

14. United States Environmental Protection Agency. Green Remediation: Incorporating Sustainable Environmental Practices into Remediation of Contaminated Sites; US-EPA: Washington, DC, USA, 2008. 
15. Moore, J.N.; Luoma, S.N. Hazardous wastes from large-scale metal extraction. A case study. Environ. Sci. Technol. 1990, 24, 1278-1285. [CrossRef]

16. Diamond, M.L.; Page, C.A.; Campbell, M.; McKenna, S.; Lall, R. Life-cycle framework for assessment of site remediation options: Method and generic survey. Environ. Toxicol. Chem. Int. J. 1999, 18, 788-800. [CrossRef]

17. Tadesse, B.; Donaldson, J.D.; Grimes, S.M. Contaminated and polluted land: A general review of decontamination management and control. J. Chem. Technol. Biotechnol. Int. Res. Process. Environ. Clean Technol. 1994, 60, 227-240. [CrossRef]

18. Shen, Z.; Jin, F.; O'Connor, D.; Hou, D. Solidification/stabilization for soil remediation: An old technology with new vitality. ACS Publ. 2019, 20, 11615-11617. [CrossRef] [PubMed]

19. Sidhu, J.P.; Ahmed, W.; Gernjak, W.; Aryal, R.; McCarthy, D.; Palmer, A.; Toze, S. Sewage pollution in urban stormwater runoff as evident from the widespread presence of multiple microbial and chemical source tracking markers. Sci. Total Environ. 2013, 463, 488-496. [CrossRef]

20. Doig, L.E.; Liber, K.J.C. An assessment of Hyalella azteca burrowing activity under laboratory sediment toxicity testing conditions Chemosphere 2010, 81, 261-265. [CrossRef] [PubMed]

21. Park, C.M.; Katz, L.E.; Liljestrand, H.M. Mercury speciation during in situ thermal desorption in soil. J. Hazard. Mater. 2015, 300, 624-632. [CrossRef] [PubMed]

22. McCann, C.M.; Peacock, C.L.; Hudson-Edwards, K.A.; Shrimpton, T.; Gray, N.D.; Johnson, K.L. In situ arsenic oxidation and sorption by a Fe-Mn binary oxide waste in soil. J. Hazard. Mater. 2018, 342, 724-731. [CrossRef]

23. Smith, L.A. Remedial Options for Metals-Contaminated Sites; Lewis Publishing Company: Ririe, ID, USA, 1995.

24. Baldwin, D.R.; Marshall, W.J. Heavy metal poisoning and its laboratory investigation. Ann. Clin. Biochem. 1999, 36, 267-300. [CrossRef] [PubMed]

25. Rosen, C.J. Lead in the Home Garden and Urban Soil Environment; University of Minnesota: Minneapolis, MN, USA, 2002.

26. Davies, B.E.; Jones, L.H.P. Micronutrients and toxic elements. In Russell's Soil Conditions and Plant Growth, 11th ed.; CAB Direct: Glasgow, UK, 1988; pp. 780-814.

27. Greaney, K.M. An Assessment of Heavy Metal Contamination in the Marine Sediments of Las Perlas Archipelago, Gulf of Panama; Heriot-Watt University: Edinburgh, UK, 2005.

28. McLaughlin, M.J.; Hamon, R.E.; McLaren, R.G.; Speir, T.W.; Rogers, S.L. A bioavailability-based rationale for controlling metal and metalloid contamination of agricultural land in Australia and New Zealand. Soil Res. 2000, 38, 1037-1086. [CrossRef]

29. Campbell, P.G. Cadmium-A priority pollutant. Environ. Chem. 2006, 3, 387-388. [CrossRef]

30. Bjuhr, J. Trace Metals in Soils Irrigated with Waste Water in a Periurban Area Downstream Hanoi City, Vietnam; Swedish University of Agricultural Sciences: Uppsala, Sweden, 2007.

31. Martınez, C.E.; Motto, H.L. Solubility of lead, zinc and copper added to mineral soils. Environ. Pollut. 2000, 107, 153-158. [CrossRef]

32. Sivakumar, G.; Xu, J.; Thompson, R.W.; Yang, Y.; Randol-Smith, P.; Weathers, P.J. Integrated green algal technology for bioremediation and biofuel. Bioresour. Technol. 2012, 107, 1-9. [CrossRef] [PubMed]

33. Wang, L.; Rinklebe, J.; Tack, F.M.; Hou, D. A review of green remediation strategies for heavy metal contaminated soil. Soil Use Manag. 2021, 37, 936-963. [CrossRef]

34. Bulgariu, L.; Bulgariu, D. Enhancing biosorption characteristics of marine green algae (Ulva lactuca) for heavy metals removal by alkaline treatment. Bioprocess. Biotech. 2014, 4, 1. [CrossRef]

35. Bestawy, E.E.; Helmy, S.; Hussien, H.; Fahmy, M.; Amer, R. Bioremediation of heavy metal-contaminated effluent using optimized activated sludge bacteria. Appl. Water Sci. 2013, 3, 181-192. [CrossRef]

36. Volesky, B.; Naja, G. Biosorption technology: Starting up an enterprise. Int. J. Technol. Transf. Commer. 2007, 6, 196-211. [CrossRef]

37. Kim, K.J.; Kim, D.H.; Yoo, J.C.; Baek, K. Electrokinetic extraction of heavy metals from dredged marine sediment. Sep. Purif. Technol. 2011, 79, 164-169. [CrossRef]

38. Cameselle, C.; Pena, A. Enhanced electromigration and electro-osmosis for the remediation of an agricultural soil contaminated with multiple heavy metals. Process. Saf. Environ. Ptotection 2016, 104, 209-217. [CrossRef]

39. Lan, J.; Zhang, S.; Lin, H.; Li, T.; Xu, X.; Li, Y.; Gong, G. Efficiency of biodegradable EDDS, NTA and APAM on enhancing the phytoextraction of cadmium by Siegesbeckia orientalis L. grown in Cd-contaminated soils. Chemosphere 2013, 91, 1362-1367. [CrossRef] [PubMed]

40. Tchounwou, P.B.; Yedjou, C.G.; Patlolla, A.K.; Sutton, D.J. Heavy metal toxicity and the environment. Mol. Clin. Environ. Toxicol. 2012, 101, 133-164. [CrossRef]

41. Meier, S.; Curaqueo, G.; Khan, N.; Bolan, N.; Cea, M.; Eugenia, G.M.; Cornejo, P.; Ok, Y.S.; Borie, F. Chicken-manure-derived biochar reduced bioavailability of copper in a contaminated soil. J. Soils Sediments 2017, 17, 741-750. [CrossRef]

42. Wang, N.; Xue, X.M.; Juhasz, A.L.; Chang, Z.Z.; Li, H.B. Biochar increases arsenic release from an anaerobic paddy soil due to enhanced microbial reduction of iron and arsenic. Environ. Pollut. 2017, 220, 514-522. [CrossRef] [PubMed]

43. Bian, R.; Joseph, S.; Cui, L.; Pan, G.; Li, L.; Liu, X.; Zhang, A.; Rutlidge, H.; Wong, S.; Chia, C.; et al. A three-year experiment confirms continuous immobilization of cadmium and lead in contaminated paddy field with biochar amendment. J. Hazard. Mater. 2014, 272, 121-128. [CrossRef] 
44. Ahmad, M.; Ok, Y.S.; Kim, B.Y.; Ahn, J.H.; Lee, Y.H.; Zhang, M.; Moon, D.H.; Al-Wabel, M.I.; Lee, S.S. Impact of soybean stover-and pine needle-derived biochars on $\mathrm{Pb}$ and as mobility, microbial community, and carbon stability in a contaminated agricultural soil. J. Environ. Manag. 2016, 166, 131-139. [CrossRef]

45. Wang, L.; Li, X.; Tsang, D.C.; Jin, F.; Hou, D. Green remediation of Cd and Hg contaminated soil using humic acid modified montmorillonite: Immobilization performance under accelerated ageing conditions. J. Hazard. Mater. 2020, 387, 122005. [CrossRef]

46. Herath, I.; Iqbal, M.C.; Al-Wabel, M.I.; Abduljabbar, A.; Ahmad, M.; Usman, A.R.; Ok, Y.S.; Vithanage, M. Bioenergy-derived waste biochar for reducing mobility, bioavailability, and phytotoxicity of chromium in anthropized tannery soil. J. Soils Sediments 2017, 17, 731-740. [CrossRef]

47. Gonzaga, M.I.; Matias, M.I.; Andrade, K.R.; de Jesus, A.N.; da Costa Cunha, G.; de Andrade, R.S.; de Jesus Santos, J.C. Aged biochar changed copper availability and distribution among soil fractions and influenced corn seed germination in a coppercontaminated soil. Chemosphere 2020, 240, 124828. [CrossRef] [PubMed]

48. Yin, D.; Wang, X.; Peng, B.; Tan, C.; Ma, L.Q. Effect of biochar and Fe-biochar on Cd and As mobility and transfer in soil-rice system. Chemosphere 2017, 186, 928-937. [CrossRef]

49. Zhang, C.; Shan, B.; Zhu, Y.; Tang, W. Remediation effectiveness of Phyllostachys pubescens biochar in reducing the bioavailability and bioaccumulation of metals in sediments. Environ. Pollut. 2018, 242, 1768-1776. [CrossRef] [PubMed]

50. Igalavithana, A.D.; Kwon, E.E.; Vithanage, M.; Rinklebe, J.; Moon, D.H.; Meers, E.; Tsang, D.C.; Ok, Y.S. Soil lead immobilization by biochars in short-term laboratory incubation studies. Environ. Int. 2019, 127, 190-198. [CrossRef] [PubMed]

51. Xing, Y.; Wang, J.; Xia, J.; Liu, Z.; Zhang, Y.; Du, Y.; Wei, W. A pilot study on using biochars as sustainable amendments to inhibit rice uptake of $\mathrm{Hg}$ from a historically polluted soil in a Karst region of China. Ecotoxicol. Environ. Saf. 2019, 170, 18-24. [CrossRef]

52. Bashir, S.; Hussain, Q.; Akmal, M.; Riaz, M.; Hu, H.; Ijaz, S.S.; Iqbal, M.; Abro, S.; Mehmood, S.; Ahmad, M. Sugarcane bagasse-derived biochar reduces the cadmium and chromium bioavailability to mash bean and enhances the microbial activity in contaminated soil. J. Soils Sediments 2018, 18, 874-886. [CrossRef]

53. Park, J.H.; Choppala, G.K.; Bolan, N.S.; Chung, J.W.; Chuasavathi, T. Biochar reduces the bioavailability and phytotoxicity of heavy metals. Plant Soil 2011, 348, 439-451. [CrossRef]

54. Li, G.; Khan, S.; Ibrahim, M.; Sun, T.R.; Tang, J.F.; Cotner, J.B.; Xu, Y.Y. Biochars induced modification of dissolved organic matter (DOM) in soil and its impact on mobility and bioaccumulation of arsenic and cadmium. J. Hazard. Mater. 2018, 348, 100-108. [CrossRef]

55. Huang, D.; Deng, R.; Wan, J.; Zeng, G.; Xue, W.; Wen, X.; Zhou, C.; Hu, L.; Liu, X.; Xu, P.; et al. Remediation of lead-contaminated sediment by biochar-supported nano-chlorapatite: Accompanied with the change of available phosphorus and organic matters. $J$. Hazard. Mater. 2018, 348, 109-116. [CrossRef]

56. Zhou, J.; Chen, H.; Tao, Y.; Thring, R.W.; Mao, J. Biochar amendment of chromium-polluted paddy soil suppresses greenhouse gas emissions and decreases chromium uptake by rice grain. J. Soils Sediments 2019, 19, 1756-1766. [CrossRef]

57. Gonzaga, M.I.; Mackowiak, C.; de Almeida, A.Q.; Wisniewski, A., Jr.; de Souza, D.F.; da Silva Lima, I.; de Jesus, A.N. Assessing biochar applications and repeated Brassica juncea L. production cycles to remediate Cu contaminated soil. Chemosphere 2018, 201, 278-285. [CrossRef]

58. Kim, H.B.; Kim, S.H.; Jeon, E.K.; Kim, D.H.; Tsang, D.C.; Alessi, D.S.; Kwon, E.E.; Baek, K. Effect of dissolved organic carbon from sludge, rice straw and spent coffee ground biochar on the mobility of arsenic in soil. Sci. Total Environ. 2018, 636, 1241-1248. [CrossRef]

59. Zhang, M.; Shan, S.; Chen, Y.; Wang, F.; Yang, D.; Ren, J.; Lu, H.; Ping, L.; Chai, Y. Biochar reduces cadmium accumulation in rice grains in a tungsten mining area-field experiment: Effects of biochar type and dosage, rice variety, and pollution level. Environ. Geochem. Health 2019, 41, 43-52. [CrossRef]

60. Zhang, J.; Wu, S.; Xu, Z.; Wang, M.; Man, Y.B.; Christie, P.; Liang, P.; Shan, S.; Wong, M.H. The role of sewage sludge biochar in methylmercury formation and accumulation in rice. Chemosphere 2019, 218, 527-533. [CrossRef] [PubMed]

61. Lyu, H.; Zhao, H.; Tang, J.; Gong, Y.; Huang, Y.; Wu, Q.; Gao, B. Immobilization of hexavalent chromium in contaminated soils using biochar supported nanoscale iron sulfide composite. Chemosphere 2018, 194, 360-369. [CrossRef] [PubMed]

62. Qiao, J.T.; Li, X.M.; Li, F.B. Roles of different active metal-reducing bacteria in arsenic release from arsenic-contaminated paddy soil amended with biochar. J. Hazard. Mater. 2018, 344, 958-967. [CrossRef]

63. Moore, F.; González, M.E.; Khan, N.; Curaqueo, G.; Sanchez-Monedero, M.; Rilling, J.; Morales, E.; Panichini, M.; Mutis, A.; Jorquera, M.; et al. Copper immobilization by biochar and microbial community abundance in metal-contaminated soils. Sci. Total Environ. 2018, 616, 960-969. [CrossRef] [PubMed]

64. Zhang, T.; Hu, L.; Zhang, M.; Jiang, M.; Fiedler, H.; Bai, W.; Wang, X.; Zhang, D.; Li, Z. Cr (VI) removal from soils and groundwater using an integrated adsorption and microbial fuel cell (A-MFC) technology. Environ. Pollut. 2019, 252, 1399-1405. [CrossRef]

65. Song, T.S.; Zhang, J.; Hou, S.; Wang, H.; Zhang, D.; Li, S.; Xie, J. In situ electrokinetic remediation of toxic metal-contaminated soil driven by solid phase microbial fuel cells with a wheat straw addition. J. Chem. Technol. Biotechnol. 2018, 93, 2860-2867. [CrossRef]

66. Wang, G.; Huang, L.; Zhang, Y. Cathodic reduction of hexavalent chromium [Cr (VI)] coupled with electricity generation in microbial fuel cells. Biotechnol. Lett. 2008, 30, 1959-1966. [CrossRef]

67. Awasthi, A.; Sharma, P.; Jangir, L.; Awasthi, G.; Awasthi, K.K.; Awasthi, K. Dose dependent enhanced antibacterial effects and reduced biofilm activity against Bacillus subtilis in presence of ZnO nanoparticles. Mater. Sci. Eng. C 2020, 113, 111021. [CrossRef] 
68. Sankhla, M.S.; Kumar, R. Contaminant of Heavy Metals in Groundwater \& Its Toxic Effects on Human Health \& Environment. Int. J. Environ. Sci. Nat. Res. 2019, 18, 555996. [CrossRef]

69. Ishii, S.; Bell, J.; Marshall, F.J.E.P. Phytotoxic risk assessment of ambient air pollution on agricultural crops in Selangor State, Malaysia. Environ. Pollut. 2007, 150, 267-279. [CrossRef]

70. Rafique, T.; Naseem, S.; Usmani, T.H.; Bashir, E.; Khan, F.A.; Bhanger, M.I. Geochemical factors controlling the occurrence of high fluoride groundwater in the Nagar Parkar area, Sindh, Pakistan. J. Hazard. Mater. 2009, 171, 424-430. [CrossRef]

71. Awasthi, G.; Singh, T.; Tiwari, Y.; Awasthi, A.; Tripathi, R.D.; Shrivastava, S.; Awasthi, K.K. A review on nanotechnological interventions for plant growth and production. Mater. Today Proc. 2020, 31, 685-693. [CrossRef]

72. Awasthi, G.; Kumar, A.; Awasthi, K.K.; Singh, A.P.; Srivastva, S.; Vajpayee, P.; Tripathi, R.D. Green synthesis of nanoparticles: An emerging phytotechnology. In Green Technologies and Environmental Sustainability; Springer: Cham, Switzerland, 2017; pp. 339-363. [CrossRef]

73. Yadav, H.; Kumar, R.; Sankhla, M.S. Residues of pesticides and heavy metals in crops resulting in toxic effects on living organism. J. Seybold Rep. ISSN NO 2020, 1533, 9211.

74. Srivastava, S. Arsenic in Drinking Water and Food; Springer: Berlin/Heidelberg, Germany, 2020. [CrossRef]

75. Sankhla, M.S.; Kumari, M.; Nandan, M.; Kumar, R.; Agrawal, P. Heavy metals contamination in water and their hazardous effect on human health-A review. Int. J. Curr. Microbiol. App. Sci. 2016, 5, 759-766. [CrossRef]

76. Katare, P.Y.; Sankhla, M.S.; Singhal, M.; Ekta, B.; Jadhav, K.P.; Bhagyashri, T.N.; Bhardwaj, L. Microplastics in aquatic environments: Sources, ecotoxicity, detection \& remediation. Biointerface Res. Appl. Chem. 2021, 12, 3407-3428. [CrossRef]

77. Sankhla, M.S.; Kumari, M.; Sharma, K.; Kushwah, R.S.; Kumar, R. Heavy metal pollution of Holy River Ganga: A review. Int. J. Res. 2018, 5, 421-436.

78. Parihar, K.; Kumar, R.; Sankhla, M.S. Impact of Heavy Metals on Survivability of Earthworms. Int. Med.-Leg. Report. J. 2019, 26, 51-57.

79. Verma, R.K.; Sankhla, M.S.; Rathod, N.V.; Sonone, S.S.; Parihar, K.; Singh, G.K. Eradication of fatal textile industrial dyes by wastewater treatment. Biointerface Res. Appl. Chem. 2021, 12, 567-587. [CrossRef]

80. Adeel, M.; Ma, C.; Ullah, S.; Rizwan, M.; Hao, Y.; Chen, C.; Jilani, G.; Shakoor, N.; Li, M.; Wang, L.; et al. Exposure to nickel oxide nanoparticles insinuates physiological, ultrastructural and oxidative damage: A life cycle study on Eisenia fetida. Environ. Pollut. 2019, 254, 113032. [CrossRef]

81. Adeel, M.; Tingting, J.; Hussain, T.; He, X.; Ahmad, M.A.; Irshad, M.K.; Shakoor, N.; Zhang, P.; Changjian, X.; Hao, Y.; et al Bioaccumulation of ytterbium oxide nanoparticles insinuate oxidative stress, inflammatory, and pathological lesions in ICR mice. Environ. Sci. Pollut. Res. 2020, 27, 32944-32953. [CrossRef]

82. Wang, Y.; Jiang, F.; Ma, C.; Rui, Y.; Tsang, D.C.; Xing, B. Effect of metal oxide nanoparticles on amino acids in wheat grains (Triticum aestivum) in a life cycle study. J. Environ. Manag. 2019, 241, 319-327. [CrossRef] [PubMed]

83. Yang, J.; Cao, W.; Rui, Y. Interactions between nanoparticles and plants: Phytotoxicity and defense mechanisms. J. Plant Interact. 2017, 12, 158-169. [CrossRef]

84. Yang, J.; Jiang, F.; Ma, C.; Rui, Y.; Rui, M.; Adeel, M.; Cao, W.; Xing, B. Alteration of crop yield and quality of wheat upon exposure to silver nanoparticles in a life cycle study. J. Agric. Food Chem. 2018, 66, 2589-2597. [CrossRef] [PubMed]

85. Hao, Y.; Ma, C.; White, J.C.; Adeel, M.; Jiang, R.; Zhao, Z.; Rao, Y.; Chen, G.; Rui, Y.; Xing, B. Carbon-based nanomaterials alter the composition of the fungal endophyte community in rice (Oryza sativa L.). Environ. Sci. Nano 2020, 7, 2047-2060. [CrossRef]

86. Rui, M.; Ma, C.; Tang, X.; Yang, J.; Jiang, F.; Pan, Y.; Xiang, Z.; Hao, Y.; Rui, Y.; Cao, W.; et al. Phytotoxicity of silver nanoparticles to peanut (Arachis hypogaea L.): Physiological responses and food safety. ACS Sustain. Chem. Eng. 2017, 5, 6557-6567. [CrossRef]

87. Adeleye, A.S.; Conway, J.R.; Garner, K.; Huang, Y.; Su, Y.; Keller, A.A. Engineered nanomaterials for water treatment and remediation: Costs, benefits, and applicability. Chem. Eng. J. 2016, 286, 640-662. [CrossRef]

88. Jafari, S.M.; McClements, D.J. Nanotechnology approaches for increasing nutrient bioavailability. Adv. Food Nutr. Res. 2017, 81, 1-30. [CrossRef]

89. Caracciolo, G.; Vali, H.; Moore, A.; Mahmoudi, M. Challenges in molecular diagnostic research in cancer nanotechnology. Nano Today 2019, 27, 6-10. [CrossRef]

90. Gashti, M.P.; Pakdel, E.; Alimohammadi, F. Nanotechnology-based coating techniques for smart textiles. In Active Coatings for Smart Textiles; Woodhead Publishing: Sawston, UK, 2016; pp. 243-268. [CrossRef]

91. Contreras, J.; Rodriguez, E.A.; Taha-Tijerina, J. Nanotechnology applications for electrical transformers-A review. Electr. Power Syst. Res. 2017, 143, 573-584. [CrossRef]

92. Contreras, J.E.; Rodriguez, E.A. Nanostructured insulators-A review of nanotechnology concepts for outdoor ceramic insulators. Ceram. Int. 2017, 43, 8545-8550. [CrossRef]

93. Hassan, D.; Khalil, A.T.; Solangi, A.R.; El-Mallul, A.; Shinwari, Z.K.; Maaza, M. Physiochemical properties and novel biological applications of Callistemon viminalis-mediated $\alpha$-Cr2O3 nanoparticles. Appl. Organomet. Chem. 2019, 33, e5041. [CrossRef]

94. Hassan, D.; Khalil, A.T.; Saleem, J.; Diallo, A.; Khamlich, S.; Shinwari, Z.K.; Maaza, M. Biosynthesis of pure hematite phase magnetic iron oxide nanoparticles using floral extracts of Callistemon viminalis (bottlebrush): Their physical properties and novel biological applications. Artif. Cells Nanomed. Biotechnol. 2018, 46, 693-707. [CrossRef] [PubMed] 
95. Khalil, A.T.; Ovais, M.; Ullah, I.; Ali, M.; Shinwari, Z.K.; Hassan, D.; Maaza, M. Sageretia thea (Osbeck.) modulated biosynthesis of $\mathrm{NiO}$ nanoparticles and their in vitro pharmacognostic, antioxidant and cytotoxic potential. Artif. Cells Nanomed. Biotechnol. 2018, 46, 838-852. [CrossRef]

96. Jin, X.; Yu, B.; Lin, J.; Chen, Z. Integration of biodegradation and nano-oxidation for removal of PAHs from aqueous solution. ACS Sustain. Chem. Eng. 2016, 4, 4717-4723. [CrossRef]

97. Prasad, K.S.; Gandhi, P.; Selvaraj, K. Synthesis of green nano iron particles (GnIP) and their application in adsorptive removal of As (III) and As (V) from aqueous solution. App. Surf. Sci. 2014, 317, 1052-1059. [CrossRef]

98. Lin, J.; He, F.; Su, B.; Sun, M.; Owens, G.; Chen, Z. The stabilizing mechanism of cadmium in contaminated soil using green synthesized iron oxide nanoparticles under long-term incubation. J. Hazard. Mater. 2019, 379, 120832. [CrossRef]

99. Zhan, J.; Huang, H.; Yu, H.; Zhang, X.; Zheng, Z.; Wang, Y.; Liu, T.; Li, T. The combined effects of Cd and Pb enhanced metal binding by root cell walls of the phytostabilizer Athyrium wardii (Hook.). Environ. Pollut. 2020, 258, 113663. [CrossRef]

100. Wang, Y.; O'Connor, D.; Shen, Z.; Lo, I.M.; Tsang, D.C.; Pehkonen, S.; Pu, S.; Hou, D. Green synthesis of nanoparticles for the remediation of contaminated waters and soils: Constituents, synthesizing methods, and influencing factors. J. Clean. Prod. 2019, 226, 540-549. [CrossRef]

101. Das, P.; Barua, S.; Sarkar, S.; Karak, N.; Bhattacharyya, P.; Raza, N.; Kim, K.H.; Bhattacharya, S.S. Plant extract-mediated green silver nanoparticles: Efficacy as soil conditioner and plant growth promoter. J. Hazard. Mater. 2018, 346, 62-72. [CrossRef]

102. Zhang, Y.; Wei, J.; Zhu, Y.; George-Ufot, G. Untangling the relationship between corporate environmental performance and corporate financial performance: The double-edged moderating effects of environmental uncertainty. J. Clean. Prod. 2020, 263, 121584. [CrossRef]

103. Al-Shnani, F.; Al-Haddad, T.; Karabet, F.; Allaf, A.W. Chitosan loaded with silver nanoparticles, CS-AgNPs, using Thymus syriacus, wild mint, and rosemary essential oil extracts as reducing and capping agents. J. Phys. Org. Chem. 2017, 30, e3680. [CrossRef]

104. Selvan, D.A.; Mahendiran, D.; Kumar, R.S.; Rahiman, A.K. Garlic, green tea and turmeric extracts-mediated green synthesis of silver nanoparticles: Phytochemical, antioxidant and in vitro cytotoxicity studies. J. Photochem. Photobiol. B Biol. 2018, 180, 243-252. [CrossRef]

105. Weng, X.; Huang, L.; Chen, Z.; Megharaj, M.; Naidu, R. Synthesis of iron-based nanoparticles by green tea extract and their degradation of malachite. Ind. Crop. Prod. 2013, 51, 342-347. [CrossRef]

106. Lehmann, J.; Joseph, S. Biochar for Environmental Management: An Introduction; Routledge: Abington-on-Thames, UK, 2015.

107. Mesa, A.C.; Spokas, K.A. Impacts of biochar (black carbon) additions on the sorption and efficacy of herbicides. Herbic. Environ. 2011, 13, 315-340.

108. Santos, R.A.C. Desenvolvimento de Método para Determinação de Agrotóxicos (Perturbadores Endócrinos) em Água; UFS: São Cristóvão, Brazil, 2016; Available online: https:/ / ri.ufs.br/handle/riufs/ 6050 (accessed on 8 December 2021).

109. El-Naggar, A.; Lee, S.S.; Rinklebe, J.; Farooq, M.; Song, H.; Sarmah, A.K.; Zimmerman, A.R.; Ahmad, M.; Shaheen, S.M.; Ok, Y.S Biochar application to low fertility soils: A review of current status, and future prospects. Geoderma 2019, 337, 536-554. [CrossRef]

110. Palansooriya, K.N.; Yang, Y.; Tsang, Y.F.; Sarkar, B.; Hou, D.; Cao, X.; Meers, E.; Rinklebe, J.; Kim, K.H.; Ok, Y.S. Occurrence of contaminants in drinking water sources and the potential of biochar for water quality improvement: A review. Crit. Rev. Environ. Sci. Technol. 2020, 50, 549-611. [CrossRef]

111. Shaheen, S.M.; Niazi, N.K.; Hassan, N.E.; Bibi, I.; Wang, H.; Tsang, D.C.; Ok, Y.S.; Bolan, N.; Rinklebe, J. Wood-based biochar for the removal of potentially toxic elements in water and wastewater: A critical review. Int. Mater. Rev. 2019, 64, 216-247. [CrossRef]

112. Lebrun, M.; Alidou Arzika, I.; Miard, F.; Nandillon, R.; Bayçu, G.; Bourgerie, S.; Morabito, D. Effect of fertilization of a biochar and compost amended technosol: Consequence on Ailanthus altissima growth and As-and Pb-specific root sorption. Soil Use Manag. 2020, 36, 766-772. [CrossRef]

113. Wang, L.; Ok, Y.S.; Tsang, D.C.; Alessi, D.S.; Rinklebe, J.; Wang, H.; Mašek, O.; Hou, R.; O'Connor, D.; Hou, D. New trends in biochar pyrolysis and modification strategies: Feedstock, pyrolysis conditions, sustainability concerns and implications for soil amendment. Soil Use Manag. 2020, 36, 358-386. [CrossRef]

114. Bio Char Plant-Bing Images Rice Husk Biochar with Beneficial Microbes: A Promising Agricultural Inoculant and Soil Ameliorant-Research Outreach. Available online: https://researchoutreach.org/articles/rice-husk-biochar-agriculturalinoculant-soil-ameliorant/ (accessed on 8 December 2021).

115. Biochar Compost FTW I Food I Forest I Garden. Available online: foodforestgarden.org (accessed on 8 December 2021).

116. World-Biochar Headlines-02-2019 Biochar Project, Biochar Australia. Available online: http://biocharproject.org/world-biocharheadlines/world-biochar-headlines-02-2019/ (accessed on 8 December 2021).

117. Leelarungroj, K.; Likitlersuang, S.; Chompoorat, T.; Janjaroen, D. Leaching mechanisms of heavy metals from fly ash stabilised soils. Waste Manag. Res. 2018, 36, 616-623. [CrossRef]

118. Zha, F.; Ji, C.; Xu, L.; Kang, B.; Yang, C.; Chu, C. Assessment of strength and leaching characteristics of heavy metal-contaminated soils solidified/stabilized by cement/fly ash. Environ. Sci. Pollut. Res. 2019, 53, 30206-30219. [CrossRef] [PubMed]

119. Liu, L.; Zhu, B.; Wang, G.X. Azoxystrobin-induced excessive reactive oxygen species (ROS) production and inhibition of photosynthesis in the unicellular green algae Chlorella vulgaris. Environ. Sci. Pollut. Res. 2015, 22, 7766-7775. [CrossRef]

120. Bhat, S.A.; Vig, A.P. Vermistabilization and detoxification of sugar industry sludges by earthworms. In Industrial and Municipal Sludge; Elsevier: Amsterdam, The Netherlands, 2019; pp. 61-81. [CrossRef] 
121. Goel, G.; Kalamdhad, A.S. An investigation on use of paper mill sludge in brick manufacturing. Constr. Build. Mater. 2017, 148, 334-343. [CrossRef]

122. Idehai, I.M.; Akujieze, C.N. Estimation of landfill gas and its renewable energy potential in Lagos, Nigeria. Int. J. Energy Environ. Eng. 2015, 6, 329-343. [CrossRef]

123. Arora, P.K.; Srivastava, A.; Garg, S.K.; Singh, V.P. Recent advances in degradation of chloronitrophenols. Bioresour. Technol. 2018, 250, 902-909. [CrossRef]

124. Bharagava, R.N.; Saxena, G.; Mulla, S.I. Introduction to industrial wastes containing organic and inorganic pollutants and bioremediation approaches for environmental management. In Bioremediation of Industrial Waste for Environmental Safety; Springer: Berlin/Heidelberg, Germany, 2020; pp. 1-18. [CrossRef]

125. Nascimento, C.W.A.D.; Xing, B. Phytoextraction: A review on enhanced metal availability and plant accumulation. Sci. Agric. 2006, 63, 299-311. [CrossRef]

126. Lal, B.; Nayak, V.; Sharma, P.; Tedia, K. Effect of combined application of FYM, fly ash and fertilizers on soil properties and paddy grown on degraded land. Curr. World Environ. 2014, 9, 531. [CrossRef]

127. Tripathi, D.M.; Singh, D.; Tripathi, S. Influence of coal fly-ash on soil properties and productivity of chickpea crop in semi-arid region of Bundelkhand. Curr. World Environ. 2020, 15, 127. [CrossRef]

128. Schwitzguebel, J. Potential of phytoremediation, an emerging green technology. In Ecosystem Service and Sustainable Watershed Management in North China. Proceedings of International Conference, Beijing, China, 23-25 August 2000; University of Cologne: Köln, Germany, 2000.

129. Tahir, U.; Yasmin, A.; Khan, U.H. Phytoremediation: Potential flora for synthetic dyestuff metabolism. J. King Saud Univ.-Sci. 2016, 28, 119-130. [CrossRef]

130. Kopittke, P.M.; Menzies, N.W. Effect of pH on Na induced Ca deficiency. Plant Soil 2005, 269, 119-129. [CrossRef]

131. Chappell, J. Phytoremediation of TCE in Groundwater Using Populus Status; Report Prepared for the USEPA Technology Innovation Office under a National Network of Environmental Management Studies Fellowship; US Environmenatl Protection Agency: Washington, DC, USA, 1997; pp. 1-38.

132. Henry, J.R. An Overview of the Phytoremediation of Lead and Mercury; US Environmental Protection Agency, Office of Solid Waste and Emergency Response: Washington, DC, USA, 2000.

133. Pilon-Smits, E. Phytoremediation. Annu. Rev. Plant Biol. 2005, 56, 15-39. [CrossRef] [PubMed] 